\title{
Mikä on oikein, mikä väärin?
}

Michael J. Sandel: Oikeudenmukaisuus. Kuinka toimia oikein? (2012). HS kirjat. 330 s. ISBN: 978-952-5557-49-7

SOFI OKSASEN menestyksekäs Puhdistus-teos mitä ilmeisimmin hyötyi siitä, että teksti muokattiin ensin draaman keinoin näytelmäksi ja vasta sitten romaaniksi. Michael J. Sandel on puolestaan luennoinut lukemattomia kertoja oikeudenmukaisuuden teemasta (lukuisiin esimerkkeihin M. J. Sandelin luennoista voi tutustua vaikkapa YouTubessa). Näistä luennoista on syntynyt alkuperäisteos "Justice. What's the right thing to do?" Luentosarjan videokoosteista päätellen teoksen rakenne muistuttaa luentosarjojen rakennetta. Ilmiselvästi tämäkin teos on hyötynyt dramatisoinnista. Sisällön muuntaminen dialogiseksi opetusprosessiksi on tuottanut selkeän sisältöjen valinnan ja lukijaystävällisen tekstin kuljetuksen sen lisäksi, että teos valaisee hyvin opettajan aiheesta kumuloitunutta pedagogista tietoa.

Teoksen alaotsikko lupaa lukijalle konkreettisia ratkaisuja. Tarkkaan ottaen Sandel ei tietysti pyri kertomaan, mikä on oikea tapa toimia, vaan valottaa keskeisiä oikeudenmukaisuuden lähestymistapoja. Teoksessa on kymmenen lukua, joissa tarkastellaan kolmen oikeudenmukaisuuteen liittyvän lähestymistavan heikkouksia ja vahvuuksia. Poliittinen filosofia ei tietystikään voi ratkaista lähestymistapojen erimielisyyksiä. Se antaa kuitenkin muodon esitetyille väitteille ja tuo moraalista selkeyttä vaihtoehdoille, joita me kansalaisina jatkuvasti ympäristössämme kohtaamme.

Teoksessa oikeudenmukaisuutta tarkastellaan hyvinvoinnin maksimoinnin, vapauden kunnioittamisen ja hyveen edistämisen lähestymistavoista. Jokainen näistä johdattaa ymmärtämään oikeudenmukaisuuden eri tavalla. Hyvinvoinnin maksimointia tarkastellaan utilitarismin näkökulmista, tarkemmin erityisesti hedonistisen utilitarismin (Jeromy Bentham) ja laatu-utilitarismin (John Stuart Mill) argumentein.
Vapauden kunnioittamista lähestytään libertarismin, Kantin ihmisyyden kunnioittamisen ja Rawlsin tasa-arvon perusteluiden näkökulmista. Hyveen edistämistä puolestaan tarkastellaan Aristoleen hyve-etiikan näkökulmasta.

Puhuessamme oikeudenmukaisuudesta pohdintamme usein liittyvät siihen, kuinka hyvien aikojen hedelmät ja raskaiden aikojen taakka jaetaan ja kuinka määritellään kansalaisten perusoikeudet. Näiden asioiden pohdinnoissa hyvinvointiin ja vapauteen liittyvät lähestymistavat ovat hallitsevia. Hyvinvointiin ja vapauteen liittyvien lähestymistapojen rajoja Sandel tarkastelee niin kahlitsemattomien markkinoiden, bonuspalkkioiden kuin positiivisen syrjinnän kaltaisten kysymysten avulla. Monien kysymyksenasettelujen kohdalla lukija törmää amerikkalaisen yhteiskunnan ja, ainakin tässä vertailussa edelleen voimissaan olevalta näyttävän, suomalaisen hyvinvointiyh- 
teiskunnan eroihin. Suomessa yksilön suhde yhteiskuntaan on perustaltaan tiukemmin säädelty erityisesti yksilönvapauksien osalta kuin amerikkalaisen suhde omaan yhteiskuntaansa. Libertarismia kannattava amerikkalainen kavahtaisi suomalaisen yhteiskunnan lainsäännöllistä holhoamista ja moraalisoivana pitämäänsä lainsäädäntöämme kuin myös tulojen ja varallisuuden amerikkalaisittain voimakasta uusjakoa. Suomalaiselle lukijalle puolestaan jotkut teoksen yksilön vapauteen liittyvät esimerkkikeskustelut ovat liki mahdottomia ymmärtää. Tässä mielessä kirjan kulttuurisidonnaisuus toimii hyvin myös yhteiskunnallisten arvoerojen havainnointiin virittäjänä.

Sandel johdattelee lukijan pohtimaan hyvinvoinnin maksimoinnin ja vapauden kunnioittamisen näkökulmien riittämättömyyttä silloin kun siirrymme pohtimaan moraalisia oikean ja väärän kysymyksiä. Tähän voitaisiin ottaa sormiharjoitelmaksi esimerkki suomalaisesta ajankohtaisaiheesta.

Syyskesällä 2012 käytiin Helsingin Sanomissa keskustelua kaunokirjallisuuden etiikasta. Keskustelu alkoi kirjailija Riikka Ala-Harjan omaisten kokemusten kuvauksilla, joissa kirjailijaa syytettiin salaa ja ilman lupaa kerätyn materiaalin käyttämisestä kaunokirjallisessa teoksessaan. Kirjailijan omaiset totesivat: "... tuntuu kuin meidät olisi raiskattu/.../kirjailija on kerännyt salaa tietoa... ja ottanut läheisen sairauden kirjansa yhdeksi pääteemaksi ilman lupaa". Omaiset halusivat nostaa julkisuuteen kysymyksen taiteen etiikasta: saako taiteilija kerätä materiaalia mistä ja miten tahansa? He vaativat, että taiteella pitäisi olla samankaltaisia eettisiä sääntöjä kuin esimerkiksi tieteessä tai journalismissa.

Kirjailija, kustantaja ja Kirjailijaliiton edustaja totesivat kukin vuorollaan, että kirjailijalla on vapaus kirjoittaa asioista taideteoksen tai kaunokirjallisuuden nimissä. Kirjailija perusteli: "Kirja on monen asian ristisiitos. Se on taideteos/.../Ympärilläni tapahtuvat asiat vaikuttavat aina teokseen niin kuin kaikilla taiteilijoilla". Kustantaja totesi: "Kirjailijan vapaus kirjoittaa ilman pelotteita tai uhkailuja on kirjallisuudessa kaiken perusta./.../Romaani ei pyri kuvaamaan todellisuutta, se on kuvitteellinen teos./../Jokainen lukee kaunokirjaa omista lähtökohdistaan". Kirjailijanliiton edustaja toteaa: "On täysin mahdotonta, että kirjailijoilla olisi yhteiset eettiset ohjeet samaan tapaan kuin journalisteilla ja tietokirjailijoilla./.../Tietokirjailijoilla ja journalisteilla kyse on faktan kirjoittamisesta, joten säännöt ovat toiset kuin fiktiossa". Kirjailijaliiton edustaja rinnastaa taiteen eettiset säännöt sananvapauden rajoittamiseen ja perustelee kantaansa sillä, että sananvapauden rajoittamisesta on esimerkkejä diktatuureista eikä se kuulu länsimaiseen demokratiaan. Voimakkain keskustelu päättyi loukatuksi itsensä kokeneiden omaisten mielipidekirjoitukseen, jossa he peräänkuuluttivat viime kädessä luottamukseen ja toisen kunnioitukseen rakentuvia ihmissuhteita.

Keskustelut taiteen etiikasta, olipa sitten kyse irti sahattujen rakkauslukkojen sulattamisesta tai faktan esittämisestä fiktiona, tuovat esille osapuolten erilaisia taiteen tekemiseen kohdistuvia odotuksia ja moraalisia argumentteja. Esimerkkikeskustelussamme taiteen edustajat vetosivat vapauden kunnioittamiseen (taiteilijan vapaudet) ja hyvinvoinnin maksimointiin (sananvapauden puolustus demokratian takeena). Omaiset vetosivat hyve-etiikkaan (luottamukseen ja kunnioitukseen perustuvat ihmissuhteet). Aristoteleen hyve-etiikan yhden perusajatuksen mukaan oikeudenmukaisuus on kunnioitusta luovaa. Jonkin käytännön teloksen pohdiskelu - tai sitä koskeva väittely - on myös järkeilyä siitä mitä hyveitä tuon käytännön tulisi pitää 


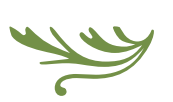

arvossa ja palkita. Esimerkissämme väittelyä käydään perimmältään taiteen teloksesta. Omaisten tunnepitoiset kokemukset ja moraalinen närkästys ovat seurausta yleisesti hyväksytyksi koettujen hyveiden laiminlyömisestä. Yksinkertaistaen omaiset näkevät kirjailijan paheina toisten kärsimyksen hyväksikäyttämisen ("kirjailija on ottanut läheisen sairauden kirjansa yhdeksi pääteemaksi ilman lupaa") ja toisaalta ahneuden ("meidän hätämme ja tuskamme oli kirjailijalle vain materiaalia, josta kustantaja tekee bisnestä"). Ahneuteen liittynee myös ajatus, että kirjailijan koetaan kirjallaan saavan jotakin sellaista, mitä hän ei ansaitse (mainetta, arvostusta ja/tai taloudellista hyötyä). Asiaa pahentaa se, että taiteen edustajat kieltäytyvät ymmärtämästä omaisten vaatimien kansalaishyveiden arvoa. Tässä keskustelussa törmäävät havainnollisesti vastakkain nykyaikaisten oikeudenmukaisuutta koskevien teorioiden yritykset erottaa toisistaan reiluutta ja oikeuksia käsittelevät kysymykset kunnioitusta, hyvettä ja moraalisia ansioita koskevista väittelyistä.

Teoksessa arkipäiväistetään mainiosti oikeudenmukaisuuteen liittyviä filosofisia kysymyksiä. Vaikka lukija vakuuttuu siitä, että useimpiin moraalisiin ongelmiin ei ole olemassa yksinkertaisia, helppoja tai "oikeita" vastauksia, saa hän työkaluja ajatustensa selventämiseksi ympärillä vellovissa moninaisissa sosiaalisissa ja moraalisissa kysymyksissä. Helppolukuisuutensa ja ymmärrettävyytensä ansiosta teos soveltuu osaksi monien tieteenalojen yleissivistäviä lukupaketteja. Parhaimmillaan teos voisi olla erilaisia yksilön ja yhteiskunnan suhdetta sivuavien, poliittisen filosofian silmälaseja hyödyntävien luentosarjojen oheislukemistona ja keskustelun virittäjänä.

Merja Ikonen-Varila dosentti, aikuiskoulutuksen yliopistolehtori Helsingin yliopisto, käyttäytymistieteiden laitos 